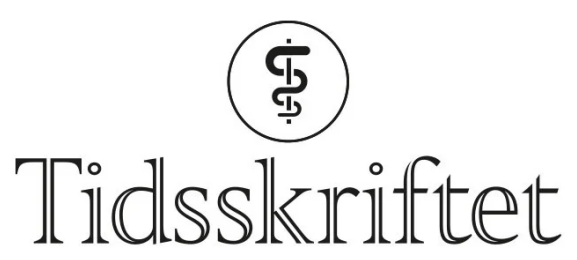

DEN NORSKE LEGEFORENING

\title{
Dannelse i koronaens tid
}

DEBATT

\section{LINN GETZ}

Linn.getz@ntnu.no

Linn Getz er lege og professor i medisinske atferdsfag ved Institutt for samfunnsmedisin og sykepleie, NTNU.

Forfatteren har fylt ut ICMJE-skjemaet og oppgir ingen interessekonflikter.

\section{I ulike roller og sammenhenger utfordres leger for tiden på måter få av oss har erfart tidligere. La oss holde hodet kaldt og hjertet varmt.}

Som gruppe betraktet er leger kompetitive. Men nå er Birken avlyst. Samtidig konfronteres vi med noen av tilværelsens grunnvilkår: usikkerhet, avmakt, sårbarhet, avhengighet, dødelighet. Kort sagt: eksistensiell uro. Sammen mobiliserer vi i etterkrigstidens største og lengste dugnad for å stoppe usynlige inntrengere som hverken er levende eller døde.

\section{Og hva skjer?}

Litt for mange av oss går i skyttergravene. Derfra kryper vi opp og sikter på hverandre. Vi kjemper om å $h a$ rett, å få rett - og om å vise det til verden. I ulike åpne og lukkede medier og kommentarfelt kommer vi med overraskende bastante, skråsikre og polariserende argumenter knyttet til pandemien. Vi maler faglige fiendebilder, kaller hverandre for selvoppnevnte eksperter, tåkeleggere og dommedagsprofeter. Jeg aner tendens til faglig klikkdannelse og kollegial underminering.

Først ulmet det. Så brøt brannen ut under møtet mellom Fredrik Solvang og Gunhild Nyborg i NRK Debatten 17. mars 2020. Norges befolkning ble rystet og splittet av programmet, og det samme ble legestanden. Bak den ene frontlinjen samlet de seg som mente at Debatt-sendingen representerte et journalistisk og medisinskfaglig havari. På den andre siden hevdet mange leger at Sannheten om pandemiens alvorlighet endelig var forløst.

I fortsettelsen er det vanskelig å føre et konstruktivt, nyansert ordskifte. Enkelte debattanter virker tidvis mer opptatt av å hakke i stykker andres synspunkter enn å bidra til utvikling av ny innsikt. 
I kraft av å være en profesjon har vi et samfunnsoppdrag. Nå innebærer det å spille (hver)andre gode og være på samme lag i arbeidet med å forstå og takle pandemien.

Jeg er ikke opptatt av mangelen på gyldig medisinsk faktakunnskap, men av måten vi fører debatt på under press. Ingen av oss kjenner den pandemiske fasiten. Det er legitimt å teste ulike kunnskapskilder, tankerekker og scenarioer. Samtidig må vi stille krav til konstruktiv, kritisk tenkning. Ordet «kritisk» henviser da ikke til det å kritisere andre, men til profesjonalitetens kjerne: dannelse. Nettopp i krisesituasjoner kommer menneskelig dannelse til sin rett.

Og hva innebærer dannelse? En relevant og tankevekkende åttepunkts liste over ønskelige profesjonelle evner finnes i rapporten Kunnskap og dannelse for et nytt århundre (ramme 1) (1).

\section{Ramme 1 Dannelsesutvalgets liste over ønskelige profesjonelle evner (1)}

1. Evnen til å forholde seg prøvende og nysgjerrig til omverdenen og til å stille interessante spørsmål om denne verden

2. Evnen til å sette faktaopplysninger inn i videre rammer, samle informasjon fra en rekke kilder og vurdere denne informasjonen på presise og fruktbare måter 3. Evnen til å underkaste et tema vedvarende og disiplinert analyse, og der det er nødvendig, med flere enn én metode eller én forståelsesform

4. Evnen til å forbinde og integrere ulike forståelsesrammer og på den måten skape kunnskap eller persepsjoner som ikke var tilgjengelig ved bruk av bare én linse 5. Evnen til å uttrykke ens tanker presist og overbevisende

6. Evnen til å ta initiativet og mobilisere egen tankekraft uten å vente på instruksjoner fra andre. Å kunne strekke seg intellektuelt

7. Evnen til å arbeide med andre på måter som frembringer et resultat som ikke kunne vært skapt på egen hånd

8. Evnen til å se seg selv som medlem av et større fellesskap, lokalt, nasjonalt og globalt, og erkjennelsen av at ens egne krefter og talenter står i tjeneste for et større, felles gode

Vi behøver ikke være «eksperter» for å bidra til debatten. Det er lov å undre seg, tenke høyt og å ta feil, så lenge argumentasjonen er gjennomtenkt og oppriktig. Det er også lov å uttale seg med snert og stil, så lenge vi ikke hoverer for mye over (hver)andre.

Jeg tok selv tydelig stilling til den omtalte debatten 17. mars, og noen kan mene at jeg nå kaster stein i glasshus. Hendelsen fikk meg i hvert fall til å betrakte det pågående ordskiftet i lys av dannelsesbegrepet. Kanskje kan noen av refleksjonene være til nytte?

Pandemidebatten preges av dikotomier som bidrar til uheldig polarisering. Hva som er «feil» og «sant» $\mathrm{i}$ en kompleks og dynamisk situasjon, er sjelden entydig. Det samme kan man si om nå/aldri og lykkes/mislykkes. La det dernest ikke gå for mye prestisje i sakene ved å spille «mitt syn» og «ditt syn» opp mot hverandre - i håp om en dag å kunne si: «Du tok feil. Hva var det jeg sa?»

Mitt dikotomivarsel gjelder også kategorisering av «eksperter» versus «ikke-eksperter». Hva som utgjør relevant ekspertise, og for hvem, avhenger både av spørsmålsstillingen og sammenhengen. Samtidig kan vi diskutere i hvilken grad, og eventuelt når og hvordan, 
leger kan kompromisse med vitenskapelig konsistens for å trenge igjennom med et velment budskap. Spørsmålet har relevans langt ut over pandemidebatten.

I omtale av noe abstrakt eller overveldende bruker vi gjerne metaforer som kan gjøre fenomenet mer gjenkjennbart og forståelig. At ord skaper virkelighet, vet både filosofer og sosiologer. Er pandemien en krig?

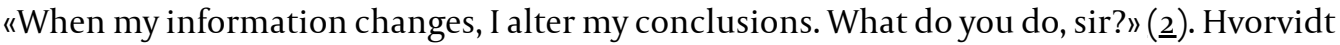
vi her har med et autentisk sitat å gjøre, er omdiskutert, men mentaliteten er forbilledlig. Det står respekt av toneangivende fagfolk og politikere som våger å være usikre, som diskuterer, justerer og tviler seg fram til en strategi. Dette skjer nå i Norge, med hele nasjonen påkoblet, minutt for minutt. Vi kan og bør bidra til å informere de sentrale beslutningsprosessene. Men jo mer uhensiktsmessig støy vi lager, jo mindre tillit får beslutningstakerne til vår profesjonalitet, og jo mindre blir vi lyttet til.

Vi lever på eksistensielt grunnfjell nå. Med ekstra behov for å bli sett og verdsatt. Jeg tenker: Når vi mennesker opptrer impulsivt, arrogant og/eller sprer frykt, er det ofte fordi vi er utilpasse og redde. Jeg skal forsøke å implementere innsikten i egen debattpraksis, blant annet slik: Når jeg blir så emosjonelt engasjert i en debatt at jeg får hjertebank, og trangen til å sette inn et verbalt nådestøt i et kommentarfelt melder seg, da setter jeg mobilen i karantene.

Etter pandemien kommer også en tid. En av lærdommene vi da kan ta fram, er at vitenskapsteori, kritisk tenkning og dannelse bør få en bredere plass i den medisinske grunnutdanningen.

\section{LITTERATUR}

1. Kunnskap og dannelse foran et nytt århundre. Innstilling fra Dannelsesutvalget for høyere utdanning, 2009: 9-10. https://w2.uib.no/filearchive/innstilling-dannelsesutvalget.pdf Lest 23.3.2020.

2. Quote Investigator. https://quoteinvestigator.com/2011/07/22/keynes-change-mind/ Lest 24.3.2020.

Publisert: 27. mars 2020. Tidsskr Nor Legeforen. DOI: 10.4045/tidsskr.20.0261

Mottatt 25.3.2020, godkjent 27.3.2020.

(C) Tidsskrift for Den norske legeforening 2023. Lastet ned fra tidsskriftet.no 26. april 2023. 